\title{
Identification of the Practicing Leadership Characteristics
}

\author{
MUHAMMAD NAVEED RIAZ \\ Department of Psychology, University of Sargodha. \\ Email: naveed.riaz@uos.edu.pk \\ Tel: +923007714217
}

\author{
HAFIZ MUHAMMAD ZEESHAN IQBAL \\ Department of Psychology, University of Sargodha. \\ Email: zeeshan.iqbal27@yahoo.com \\ Tel: +923036621155
}

IRFAN EJAZ

Department of Psychology, University of Sargodha. Email: irfanijaz2322@gmail.com

Tel: +923318797701

\begin{abstract}
The present content-analytic study of the memoir "In the Line of Fire" by Musharraf (2006) aimed at the exploration of the prevalent themes in the context of leadership practices of Musharraf especially with reference to post $9 / 11$ scenarios. The main aim of the study was to explore the major leadership qualities of Musharraf through the content analysis of the memoir. After reading between the lines and with the help of the committee approach, 12 themes were derived to serve the purpose of thematic analysis from the leadership perspective. The autobiography comprised of six chapters. Each part was considered as a unit of analysis. Thus, the book was divided into six units. A 5-point rating scale was devised to enumerate the strength of each theme on the basis of their degree of intensity. The results through the enumeration system included the strength of each theme in each unit and the sum of all themes in all units. Themes were found in order of their correspondent strength in the memoir, (1) leadership during stress, (2) followers, (3) freewill versus determinism, (4) narcissism, (5) leadership ethics, (6) state of conflicts and conflict handling, (7) power and influence, (8) communication, (9) decision making, (10) motivation to lead, (11) leadership development through education, training, and experience, and (12) vision respectively. Validity of the study was maintained through the selection of the themes with the help of committee approach. Reliability of the scoring system was maintained through partial inter-rater reliability. Textual elaboration of themes was discussed.
\end{abstract}

Keywords: Leadership, Vision, Decision Making, Power, Conflict Handling, Communication, Motivation.

\section{Introduction}

The origin of the empirical work on leadership can be traced back into world wars when military-led campaigns were dominating the most of the regions of the world. Right after world war one, leadership studies were conducted known as Ohio State Studies. After the world was two, again leadership studies were conducted known as University of Michigan Studies (Northouse, 2007). In the majority of the leadership research, identifying leadership qualities, traits, and characteristics has been the central focus of the researchers (Kinicki \& Kreitner, 2006). Military leadership is the combination of many qualities and skills (Atta, 2004). Yukl and Taber (2002) integrated 50 years of leadership research and summarized it to 
three behaviors including task, relations, and change behavior. The research is conducted to address certain research questions. The research is based on the assumption the contextual factors like the incident of 9/11 directly influenced the leadership practices of a military leader of Pakistan i.e. Musharraf. The research also focusses of the assumption that leaders carry some distinct qualities which determine the nature of their leadership.

\section{Research Objectives}

- The study aimed to explore the leadership qualities of a military leader in Pakistan by the content analysis of his memoir.

- Moreover, the present study aims to explore the prevalent themes in the memoir "In the Line of Fire" especially with reference to the leadership practices of Musharraf in the context of 9/11 and war against terrorism.

- To explore the leadership dynamics through the memoir highlighting the personal and professional life experiences of a military leader who led a state as well.

\section{Literature Review}

Manning and Curtis (2003) identified ten leadership qualities including vision, ability, enthusiasm, stability, concern for others, self-confidence, persistence, vitality, charisma, and integrity. Riaz (2009) illustrates that prime responsibility of a leader is decision making because decisiveness splits strong leadership from its weak counterpart (Muchinsky, 2007). Almas (2007) argue that leader is responsible for managing conflict among followers as leaders face multiple functional and dysfunctional conflicts (Rahim, 2001). Hassan (2003) illustrates that effective communication is a prominent leadership quality. Bass and Reggio (2006) argue that giving an inspiring vision is the core responsibility of a leader. Similarly, it is a leader's responsibility to be motivated and to motivate the followers toward goals. Effective leaders empower their followers through various means (Avolio \& Bass, 2002). French and Raven (1959) argue that leadership is the process of influencing followers and the leaders use multiple powers to influence followers including reward, referent, coercive, legitimate, and expert power. Situational perspective on leadership illustrates that leadership effectiveness depends on the role of leader, followers, and situational factors (Goleman, 2000). Dixon (1976) illustrates that a military leader should possess the qualities of trustworthiness, sincerity, bravery, and omniscience. Leadership is affected by multiple factors especially training and education plays a vital role in leadership (Riaz, Haque, \& Hassan, 2009).

Research on military leadership is very contextual in nature. Like world wars, researchers conducted numerous studies after all important military incidents. It is because military leadership is greatly affected by the situational factors, abrupt changes, crisis, and historical incidents (Quinn, 1988). Consequently, the researchers content analyzed the speeches, diaries, and autobiographies of the military leaders after important endeavors. The value-based appealing styles during WWII were analyzed through the content analysis of the public speeches of the Hitler and Roosevelt. The findings indicate that Hitler focused on the values related to morality and strength whereas Roosevelt stressed economic values (White, 1949). Majority of the military leadership literature stems from the content analysis of the personal documents of the great military leaders including biographies and autobiographies (Akhtar, 1991). Researchers content analyzed the personal documents of the revolutionary leaders including Washington, Hamilton, Trotsky, Stalin, and Mao Tze Tang. The researchers discovered that Washington, Stalin, and Mao Tze Tang appeared as successful leaders in the history because of the conceptual simplicity whereas Hamilton and Trotsky appeared to be unsuccessful leaders due to their too much conceptual complexity (Suedfield \& Rank, 1976). Satterfield and Seligman (1994) content analyzed the verbatim of the Saddam and Bush during the Gulf war. The researchers found that both leaders took passive actions when they were pessimistic in their verbatim and both took bold actions when they were optimistic in their verbatim. 
Just like World War I, World War II, and Gulf Crisis, the war against terrorism was an important incident in the world history which caused an abrupt change in the world polities. In fact, 9/11 was a day which changes the entire world. It was a war against an invisible enemy or a war against shadows (Musharraf, 2006). The memoir "In the Line of Fire" is an important autobiography written in the context of 9/11. The book appeared as the second highest selling book due to the controversies in the book and the massive criticism. The memoir is not only the autobiography of a military leader in Pakistan but also a glimpse of military regime in the country (Riaz, 2006). Military regimes occupy half of the history of since Pakistan emerged on the world map and military leadership had vital involvement in the political, economic, educational, and social changes in the country (Akhtar, 1991). Shaugnessy, Walding and Kurds (2006) illustrate that archival research can facilitate us in understanding various political scenarios and can help us in predicting the futuristic events in the world.

\section{Methods}

The present study is based on the thematic analysis of the memoir "In the Line of Fire". First of all, the English version of the memoir "In the Line of Fire" was selected as the research sample to be content analyzed right after it was published on September 25, 2006 written by Pervez Musharraf. Memoir is a type of autobiography in which the author describes his or her important life incidents. Thematic analysis is a type of content analysis in which prominent themes in the content are analyzed. Content analysis comprises of three processes including (a) identifying the categories of analysis, (b) dividing the information into units of analysis and (c) enumerating the units (Shaughnessy, Walding, \& Kurds, 2006).

The first important decision was to generate the themes in the content of the memoir. Themes in the book were selected through committee approach. The book was personally read by the author for 10 times and then it was referred to six experts to read the book between the lines. Two experts were taken from the discipline of psychology. Two of the experts were from the discipline of international relations and the other two experts were from the discipline of Pakistan studies. The experts were instructed to read the book between lines and identify the major qualities of the author with reference to military leadership. Thus, the themes were selected in collaboration with the suggestions of the committee. Reading between the lines, 12 themes were generated that showed their relevance with the mainstream military leadership (see table 1).

Table No 1 : Themes, Their Titles and the Description of the Themes

\begin{tabular}{|l|l|l|}
\hline Themes & Theme Title & Description of the Theme \\
\hline Theme 1 & $\begin{array}{l}\text { Leadership development } \\
\text { through } \\
\text { training, and experience }\end{array}$ & $\begin{array}{l}\text { This theme incorporates the assumption of the behaviorists } \\
\text { that leaders are made not born and leadership is developed } \\
\text { with the help of education, training, and experience. }\end{array}$ \\
\hline Theme 2 & Vision & $\begin{array}{l}\text { Vision involves a futuristic picture and it is considered one of } \\
\text { the most essential elements of effective leadership in the } \\
\text { modern leadership literature. }\end{array}$ \\
\hline Theme 3 & Decision making & $\begin{array}{l}\text { Decision making involves multiple styles of making decision } \\
\text { including participative, consultative, autocratic, pseudo- } \\
\text { participative, and pseudo-consultative decision-making style. }\end{array}$ \\
\hline Theme 5 & Power and influence & $\begin{array}{l}\text { Followers are the people who are led by the leader. This } \\
\text { theme incorporates the perception of the leader about his } \\
\text { followers in military and about the masses of Pakistan. }\end{array}$ \\
\hline Theme 6 & Motivation to lead & $\begin{array}{l}\text { Power and influence refer to the ability of the leader to } \\
\text { control the people and events. The expert, referent, legitimate, } \\
\text { reward, and coercive are different types of leadership powers. }\end{array}$ \\
\hline
\end{tabular}




\begin{tabular}{|l|l|l|}
\hline Theme 7 & $\begin{array}{l}\text { State of conflicts and } \\
\text { conflict handling }\end{array}$ & $\begin{array}{l}\text { Conflicts are functional and dysfunctional in nature. Conflict } \\
\text { handling strategies are used to manage conflicts in including } \\
\text { obliging, dominating, avoiding, compromising and integrating }\end{array}$ \\
\hline Theme 8 & $\begin{array}{l}\text { Freewill versus } \\
\text { determinism }\end{array}$ & $\begin{array}{l}\text { Freewill refers to believe in free choices in life whereas } \\
\text { determinism is the belief in chances factors, situations, and } \\
\text { circumstances as possible explanation of behaviors. }\end{array}$ \\
\hline Theme 9 & Narcissism & $\begin{array}{l}\text { Narcissism is a tendency of a person to exaggerate his } \\
\text { importance. It involves increased levels of self-love and self- } \\
\text { importance and belief in enchanted personal abilities. }\end{array}$ \\
\hline Theme 11 & Leadership ethics & $\begin{array}{l}\text { Communication is the exchanges of ideas and information. } \\
\text { Communication can be categorized into defensive, assertive } \\
\text { and aggressive styles of conveying information and messages. }\end{array}$ \\
\hline Theme 12 & Leadership and stress & $\begin{array}{l}\text { Leadership ethics involve personal values and code of } \\
\text { conduct. Traditional religious values split with the liberal and } \\
\text { secular values in the collectivist society of Pakistan. }\end{array}$ \\
\hline
\end{tabular}

The second important decision was to divide the information into coding units. This decision was also taken with the help of committee approach. A committee of four experts from psychology was assigned the task to devise the units of analysis. The structure of the memoir was itself helpful in this regard. The memoir comprised of six parts. Thus, the memoir's distribution into predefined six parts provided the committee an insight to consider each part as a separate unit. Thus, six units were identified as each part as a single unit of analysis. Introductory and concluding ages were included in the first and the last unit respectively (see table 2 ).

Table No 2: Units of analysis, their associated parts and titles of the units including page numbers in the

\begin{tabular}{|l|l|l|l|}
\hline $\begin{array}{l}\text { Unit } \\
\text { No. }\end{array}$ & Part No. & Part Title & Page No. \\
\hline Unit 1 & Part 1, preface and prologue (Chapter 1 to 5) & In the Beginning & $1-35$ \\
\hline Unit 2 & Part 2 (Chapter 6 to 11) & Life in the Army & $39-98$ \\
\hline Unit 3 & Part 3 (Chapter 12 to 15) & The Hijacking Drama & $101-140$ \\
\hline Unit 4 & Part 4 (Chapter 16 to 19) & Rebuilding the Nation & $143-196$ \\
\hline Unit 5 & Part 5 (Chapter 20 to 26) & The War on Terror & $199-280$ \\
\hline Unit 6 & Part 6, including epilogue (Chapter 27 to 32) & Pakistan at Home and Abroad & $283-335$ \\
\hline
\end{tabular}

The third important decision was to devise a system of enumeration for the coding of the themes into units. Degree of intensity was measured in this study. For this purpose, a five-point rating scale was developed to measure the degree of intensity of the themes regarding their corresponding coding units. In this step a couple of experts were invited to rate the intensity of the concerned themes. The reliability of the present study was maintained by partial inter-scorer reliability in which experts were asked to carefully read the text and rate the intensity of the themes on 5-point rating scale.

\section{Analysis}

According to 5-point rating scale, strength of each theme has been presented in the table. Rating involves measuring the degree of intensity or strength of a predefined theme in a specific coding unit. On the rating scale, the highest intensity included 5 and the lowest intensity included 1 . Three scores i.e. the researcher and the couple of experts rated all the themes in all units. The partial agreement between the raters- 
agreeing at least two raters among the three-was the criteria for assigning a specific number to theme in a unit. Corresponding numbers of 12 themes and the selected units of analysis are given in the Table 1.

Table No 3: Strengths of Themes in Corresponding Coding Units

\begin{tabular}{|c|c|c|c|c|c|c|c|c|}
\hline \multirow[b]{2}{*}{ Themes } & \multirow[b]{2}{*}{ Theme Title } & \multicolumn{7}{|c|}{ Units of Analysis } \\
\hline & & $\begin{array}{c}\text { Unit } \\
1\end{array}$ & $\begin{array}{c}\text { Unit } \\
2\end{array}$ & $\begin{array}{c}\text { Unit } \\
3\end{array}$ & $\begin{array}{c}\text { Unit } \\
4\end{array}$ & $\begin{array}{c}\text { Unit } \\
5\end{array}$ & $\begin{array}{l}\text { Unit } \\
6\end{array}$ & Total \\
\hline Theme 1 & Leadership development & 4 & 5 & 2 & 2 & 1 & 1 & 15 \\
\hline Theme 2 & Vision & 3 & 2 & 1 & 2 & 2 & 5 & 15 \\
\hline Theme 3 & Decision making & 1 & 2 & 2 & 3 & 4 & 4 & 16 \\
\hline Theme 4 & Followers & 5 & 2 & 2 & 3 & 5 & 4 & 21 \\
\hline Theme 5 & Power and influence & 2 & 2 & 5 & 1 & 5 & 3 & 18 \\
\hline Theme 6 & Motivation to lead & 2 & 3 & 1 & 2 & 5 & 5 & 18 \\
\hline Theme 7 & $\begin{array}{l}\text { State of conflicts and conflict } \\
\text { handling }\end{array}$ & 5 & 3 & 3 & 3 & 1 & 1 & 16 \\
\hline Theme 8 & Freewill versus determinism & 5 & 4 & 3 & 2 & 1 & 4 & 19 \\
\hline Theme 9 & Narcissism & 1 & 5 & 5 & 2 & 2 & 3 & 19 \\
\hline Theme 10 & Communication & 5 & 3 & 5 & 2 & 5 & 5 & 25 \\
\hline Theme 11 & Leadership ethics & 5 & 3 & 3 & 2 & 3 & 5 & 21 \\
\hline Theme 12 & Leadership and stress & 3 & 2 & 2 & 3 & 5 & 5 & 20 \\
\hline
\end{tabular}

Note. Unit 1 = In the Beginning (Part 1, including preface and prologue); Unit $2=$ Life in the Army (Part 2); Unit $3=$ The Hijacking Drama (Part 3); Unit $4=$ Rebuilding the Nation (Part 4); Unit $5=$ The War on Terror (Part 5); Unit $6=$ Pakistan at Home and Abroad (Part 6, including epilogue).

Each theme could get possibly maximum scores of 6 x $5=30$ in all of six units. Results in Table showed that 25 were the highest scores for theme 12 which corresponds to leadership during stress. The second highest score for theme 4 and theme 11 is 21 and it is incorporated with followers and freewill versus determinism. The third highest score is 20 for theme 12 and it is related to narcissism. The fourth highest score is 19 and it occupies theme 8 and theme 9 which are related to leadership ethics and state of conflicts and conflict handling respectively. The fifth highest score is 18 on theme 5 and theme 6 . These themes are related to power and influence and communication respectively. The sixth highest score for theme 3 and theme 7 is 16. These themes correspond decision making and motivation to lead respectively. The sixth highest score for theme 1 and theme 2 is 15 . These themes refer to leadership development through education, training, and experience and vision respectively (see table 1).

\section{Discussion}

The present study was carried out to analyze the content of the memoir "In the Line of Fire". Like formal literary novels, the memoir did not comprise of a single unified idea instead it was a storehouse of diverse issues, historical and contemporary events, and complex interplay of national and international issues. Elaboration of the themes with reference to the military leadership was carried out. All the themes were present with their varying intensity and providing us information about the content of the Musharraf's memoir as indicated by the results. Some of them were more prominent than others. These all helps in understanding the phenomenon of military leadership in Pakistan. The book also reflected the portrayal of Pakistan in the context of certain national and international events.

Results showed that leadership during stress was the most prominent theme in the memoir. Effectiveness of leadership is examined when leaders face crisis. Most of the Pakistani leaders faced devastating crisis in their regimes e.g. war of 1948 in Quaid-I-Azam's era, war of 1965 in General Ayub Khan's era, war of 1971 in General Yahya Khan's era, and Russian invasion in Afghanistan in 1978 during General Muhammad Zia-ul-Haq's era. Beside these wars, natural disasters, man-made disasters, economic depression, and political instability are the other major stressors faced by the Pakistani leaders in different 
historical spans. While characterizing the low, medium and high stress occupations, Mcshane and Travaglione (2004) illustrate that leading a state is included in the list of high-stress occupations. The incident of 9/11 appeared as the most stressful incident during the Musharraf's regime. Musharraf (2006) states "Then came 9/11 and its aftermath. The whole world changed" (p. 332).

After 9/11, USA secretary of the state Richard Armitage threatened Musharraf for support in the war against terrorism "than we should be prepared to be bombed back to the Stone Age" (p. 201) and as a result, Musharraf complied with the US-demands. After Musharraf's decision to help USA as a front-line ally, Pakistan faced multiple crisis in the form of suicide bombing and armed conflicts with Pakistani Taliban in different regions of the country. Almost 45000 civilians and 5000 personnel of armed forces were laid to death in Pakistan during the war against terrorism. "The United States was not the only causality of $9 / 11$. The attacks hit Pakistan differently, but with equal savage force. No other country has faced as much threats as many fronts" (p. 222). "During, the period that I have been at the helm of affairs, I have faced one crisis after another" (p. 331). The second highest theme is incorporated with followers and freewill versus determinism. In the memoir, Musharraf portrays a positive and optimistic image of the people of Pakistan. Musharraf (2006) illustrates "Our nation will play a key role in the developing story of the twenty-first century" (p. 277).

Freewill versus determinism has been the focus of multiple personality theories in psychology (Schultz \& Schultz, 2006). People with freewill believe in free choices in their life whereas people with determinism believe in chances factors, situations, and circumstances as possible explanation of their behaviors. In the memoir, Musharraf (2006) appears with determinism "It is also of course my own story, expressed in my own way, about an eventful, turbulent life in which both luck and destiny played leading roles" (p. xii). "I have confronted death and defied it several times in the past because destiny and fate have always smiled on me" (p. 1). "Little did I known that on the other side of the globe, yet another event involving aircraft was about to alter the course of my life" (p. 199).

Modern research views belief in freewill positively and belief in determinism negatively. Research (Baumeister, Masicampo, \& Nathan, 2009; Vohs, Jonathan, \& Schooler, 2008) in the domain of free-will versus determinism indicates that people's belief in free will and determinism directly affects their subsequent behaviors. Baumeister, Masicampo, and Nathan (2009) discovered that not having belief in free-will was linked with decreased levels of helpfulness and increased levels of aggression. Similarly, Vohs, Jonathan, and Schooler (2008) found that people with distorted beliefs in free-will were more likely to cheat others.

The third highest score is related to narcissism. Selfishness is one of the basic ingredients of narcissism (Campbell \& Foster, 2007). Pakistan's foreign policy was based on "live and let live" since its creation. Musharraf raised the slogan of "Pakistan first" (p. 143) and allowed US-coalition to attack Afghanistan from Pakistan's soil. It was good to have a realistic foreign policy based on the self-interests of the state but it was rather selfish strategy to ruin a neighboring country just for personal interests. Narcissism is related to expurgated sense of self-importance and increased levels of self-love. Reading this book, the reader has an impression that "Pakistan is first" and Musharraf is Pakistan. Musharraf justifies his takeover "we stood at the brink of being declared a failed state, a defaulted state, or even a terrorist state" (p. 139).

The fourth highest score are related to leadership ethics and states of conflicts respectively. Exploring the leadership ethics is under the current interest of the researchers (Ciulla, 2003; Johnson, 2005). John Locke states the newborn as a blank slate on which the course of his life would be written. In this regard, parents play a vital role in the ethical development of an individual. Musharraf (2006) illustrates "My character traits were instilled in me by my parents through direct teaching and personal example" (p. 329). 
Musharraf portrayed a liberal ideology and his vision enlightened moderation was also based on liberal ideology. Musharraf's ideology stems from his parent liberal values - a part from traditional Pakistanis values - as mentioned above and his entire education either in the missionary schools of Pakistan or in the secular society of Turkey.

States of conflicts is also in important theme in the memoir. Musharraf has mentioned a number of conflicts in the book. These conflicts in the book appear as the central cause of military intervention in the country. Overall, there are four causes of military takeover which include conflicts between prime ministers and presidents, conflicts between prime ministers and army chiefs, crisis situations / corruption, and those people who instigate army to takeover. "The army's reaction to Nawaz Sharif's attempted coup has not to be seen a response to another humiliation by a prime minister, but also to the abysmal political, social and economic conditions that Pakistan had reached" (p. 139).

Just like former military leaders in Pakistan, Musharraf also used a dominating conflict handling style and took over the government which resulted in the fourth-time intervention of the military into the country. Dominating conflict handling style involves a win-lose situation in which one gets on the expense of the other (Rahim, 2001). Past research links dominating conflict management style to negative outcomes (Rahim, 1992; Rahim \& Bonoma, 1979; Thomas, 1976).

The fifth highest scores are related to power and influence and communication respectively. Power refers to the leader's ability to control over events and people. Usually, leaders practice five types of power including reward, coercive, legitimate, expert, and referent power (French \& Raven, 1959). In his early life, Musharraf appeared as a man extensively using coercive power. Sometimes he defeats his opponents are becomes famous a dada geer, other times he engages in the war planning with opponent gangs. Before 9/11 Musharraf used referent power but after $9 / 11$ used coercive power. The memoir indicates that all the masterminds of the military takeover of 'the countercoup' had close ties with Musharraf. This indicates the use of referent power by the author as the countercoup was completed even in the absence of Musharraf. "The officers critical to the countercoup in the other cities were also my appointee" (p. 121).

After 9/11, the leadership practices of Musharraf completely changed. The referent power converted into excessive use of coercive power. In this regime, numerous military operations were launched in the country including Waziristan Operation, Lal-Masjid Operation, and Baluchistan Operation. Controversy exists on all of these operations in Pakistan. Especially Lal-Masjid operations were widely condemned by the masses in Pakistan. This operation promptly defamed army and resulted in suicide bombing and direct armed conflict with the personnel of Pakistan Army throughout the country. Consequently 5000 army personnelincluding officers and soldiers - were laid to death. "Little did I known that we were about to be thrust into the front line of yet another war" (p. 199). "Some are known to the world, some are not. We have captured 689 and handed over 369 to the United States" (p. 237).

Not only the war against terrorism but also the Musharraf's attempt to handover many Pakistanis to US was widely condemned in the country - especially when Musharraf claimed to receive dollars in response to these activities. One of those individuals who were handed over to US was Afghan ambassador. Geneva Convention and international low no longer permits a serving military leader to humiliate an ambassador in this way-i.e. to hand over an ambassador to his enemy country. There are generally three influence outcomes of power which include commitment, compliance and resistance. Expert and referent power leads to commitment, legitimate power results in compliance and coercive power leads to resistance (Muchinsky, 2007). Coercion is based on threats and punishments. Leaders who involve in coercion are more interested in their self-interests and less interested in their followers' needs (Northouse, 2007).

Origins of the use of coercive power in leading countries can be traced back into Machiavelli's writings. In 1513, the famous Italian philosopher Niccolo Machiavelli published his book entitled "The Prince" in which he proposed straightforward self-centered strategies to use and manipulate people in order to take 
hold of political power. The most important principles were: (1) never show humility as arrogance is far more effective when dealing with people, (2) morality and ethics are for the weak as powerful people feel free to lie, cheat, and deceive whenever it suits their purpose, and (3) it is much better to be feared than loved (Greenberg \& Baron, 2000). Dixon (1976) in his book "The Psychology of Military Incompetence" illustrates that some people become military leaders just because of their dominant psychopathic traits and by joining the military, they are able to release their antisocial impulses on others.

Communication is also an important theme in the memoir. The memoir exhibits a straightforward militarystyle communication. Musharraf's statement "Often I have been chastised for being too forthright and candid and I trust you will find these qualities reflected here" (p. xi). Musharraf's statement about Baluchistan "We will hit you in a way that you don't know what hit you" was widely criticized in the country. However, in the context of $9 / 11$, the memoir suggests multiple insights in understanding the nature and solution of the terrorism. "However, there are extremists in our midst who are neither poor nor uneducated. What motivates them? I believe it is their revulsion at the sheer pathos of the Muslim conditions: the political injustices, societal deprivation, and alienation that have reduced many Muslims to marginalization and exploitation. This accounts for the likes of Osama bin Laden, Dr. Ayman al Zawahiri, Khalid Sheikh Muhammad, and Omar Saeed heikh — all rich and educated - two of whom attended school and college in the United States and Britain and one of whom were British born" (p. 201). "But ultimate success will come only when the roots that cause terrorism are destroyed: that is, when injustices against Muslims are removed and this lies in the hands of west, particularly America" (p. 280).

It is easy to say and advice others but it is difficult to do and set a personal example. A leader-i.e. Musharraf - who claims "mind-sets cannot be changed by force" and "they must be transformed through superior logic and action" (p. 280) killed thousands of the people in his country by launching multiple military operations - e.g. Lal-Masjid Operation, Waziristan Operation, and Baluchistan Operation against famous political leaders Nawab Akbar Bugatti. Similarly, the issue of missing persons in Pakistan is also one of the most widely criticized matters in the country.

The sixth highest score corresponds to decision making and motivation to lead respectively. Leaders use multiple decision-making styles including participative, consultative, autocratic, delegatory, pseudoconsultative, and pseudo-participative decision-making style (Ali, 1989). Musharraf used autocratic and pseudo-consultative decision-making style. "I made a dispassionate, military-style analysis of our options. Emotion is all very well in drawing rooms, newspapers editorials, and movies but cannot be relied on for decisions like this. It is time like those that the leader is confronted by his acute loneliness" (p. 201).

This indicates that Musharraf's decision to join US in the war against terrorism was autocratic and he did not consider the masses emotions and the wide-spread public opinion portrayed in the print and electronic media. Dixon (1976) illustrates that military leadership is mostly autocratic. The statement given below shows that Musharraf has tendencies of pseudo-consultative decision making in which people are consulted but the leaders take standalone decisions without incorporating the advices of the concerned people. "He may listen to any amount of advice he chooses. But at the end of the day the decision has to be his alone" (p. 201).

The effectiveness and ineffectiveness of a decision can be judged by its outcomes (Riaz, 2009). Time proved that Musharraf's decision to join the war against terrorism was wrong. About 45000 causalities of the civilians, 5000 causalities of the military personnel, and US drone strikes killing innocent citizens are one of the outcomes of the Musharraf's decision. American defeat in Afghanistan also proved that the initiative of war against terrorism was wrong. Even after 10 years of war by International Security Assistance Force (ISAF), North Atlantic Treaty Organization (NATO), Afghan National Army (ANA) and United States of America (USA), Afghan Taliban are still undefeated. 
Motivation to lead is another important theme in the memoir. People are either intrinsically motivated or extrinsically motivated to lead (Myers, 2006). Most of the time, Musharraf appears to be extrinsically motivated to lead the army and the country. Musharraf illustrates that his childhood exposure to military personnel motivated him to join army. Later on, instead of personal motivation, his mother motivated him to join army. "There were two military attaches at our embassy-colonels Mustafa and Ismail—whose smart ceremonial uniforms attracted me to the army at a very young age" (p. 23). "At this point my mother decided that I would go into the army. And so, it came to me" (p. 30).

Along with the motivation to lead the army, Musharraf's motivation to lead the country also stems from extrinsic factors. Myers (2006) argues that extrinsic motivation is relatively less effective than intrinsic motivation. Musharraf (2006) illustrates that "I took over in extremely unusual circumstances, not of my making" (p. 149). "Have you ever been thrown into the deep end of a swimming pool? This is exactly how I felt when I reached Army House in Rawalpindi on the morning of October 13, 1999. I had been thrown into the deep end" (p. 143).

McClelland illustrates that there are three types of leadership motives including achievement, affiliation, and power (Mcshane \& Travaglione, 2004). In the book, Musharraf's prominent motive of leadership appears power seeking. He appears to be dada geer, fighting with bully, and making gangs in the early years of life.

The seventh highest score refer to leadership development through education, training, and early life experience and vision respectively. Research (Riaz, Haque, \& Hassan, 2009) indicates that education, training, and experience directly affect the leadership style. In military, leaders are made, just like the behavioral theorists claims that leaders are made, not born (Sekaran, 2008). Experience is the great teachers and especially the childhood experiences play a vital role in the later year development of the personality. Musharraf early life experiences helped him during the later years of his army life. "Like neighborhoods the world over, ours had boys' gangs. Even at that age I was very good at making strategies and planning tactics to ambush and trap other gangs" (p. 22). "It was in FC College that I learned how to make a time bomb, which I later used as a commando to good effect" (p. 33). Just like early life experiences, training in the Pakistan Military Academy (PMA) and education at National Defense College (NDC) also played a vital role in the leadership development of Musharraf. "A military academy is a great place to learn how to be a man who can deal with a crisis, provided it is a good military academy. The PMA is the best in the world" (p. 41).

Vision is another important theme of the memoir. Leadership researchers (Bedeian \& Hunt, 2005) illustrate that leadership requires providing a compelling vision, communicating that vision, and the ability to introduce the direction to pursue that goal. Musharraf created his vision enlightened moderation in order to shrink the distances between the west and the Muslim world. "The idea of enlightened moderation dawned on me in my study room one night when I was mediating on all this. To stop violence, we need a global solution" (p. 295). Musharraf was principally inspired by the ideology of Mustafa Kamal Pasha-the secular leader of modern Turkey post WWI. Thus, he attempted to implement his vision in a Turkish- style which was no longer appreciated and supported in the country. Even the Pasha's secular ideology was rejected by the masses in Turkey and a pro-Islam political party named Justice and Development Party three times led the elections in the country.

In such type of autobiographies, some important issues are ignored-either intentionally or unintentionally - by the writers. Similarly, some issues are underestimated while others are overstated by the authors. For example, Field Martial Muhammad Ayub Khan in his autobiography "Friends not Masters" has written 70 pages on the successfulness of his foreign policy but he did not mention even a single foreign minister's name in the entire book (Shahab, 2006). In the same manner every sentence of the Musharraf's memoir has been criticized by Pakistani media and masses which leave this book not much reliable. Most of the concerned people have rejected the issues written in the memoir for providing fake 
information and they have reported it a black propaganda on the part of writer to defame his opponents. Even the international community has criticized this book for providing misinformation. India and United Arab Emirates banned this book. One of the many reasons that this book was extremely criticized by Pakistani community is that Musharraf disclosed state secrets in his book because the state law no longer permits a serving man to publish such material.

Although the author and the memoir are controversial and not much reliable but still the present study has many implications. The study is an initiative to understand a military leader's leadership practices especially in the context of an important incident of 9/11. Just like WWI and WWII were instrumental in determining the fate of the Nazi Germany and the allied, 9/11 was also instrumental in political, social, economic, and military restructuring of the world in general and Pakistan in particular. The study is a mirror for the ruling class of the other nations in general and for the Pakistani leaders in particular to identify their deficiencies in their leadership practices. For example, time proved that Musharraf's autocratic decision to join the war against terrorism was wrong and went costly for Pakistan. Similarly, the decision to use coercive power in the form of controversial military operations in general and Lal-Masjid operation in particular resulted in 50000 causalities - 5000 army men and 45000 civilians - due to suicide bombing and the armed conflicts. Similarly, the study discusses multiple leadership themes that can be helpful in understating the important aspects of the leadership practice. For example, the study is beneficial in understating the role of motivation, power, education, training, early experiences, communication, vision, conflicts, and decision making of a leader. The outcomes of these leadership characteristics in the last years proved their effectiveness and ineffectiveness. By keeping in view, the mistakes committed by the leader during his regime, one can improve his or her leadership practices.

\section{Conclusion}

The present study aimed at content analysis of the memoir "In the Line of Fire" by Musharraf (2006). A total of 12 themes were generate from the autobiography that were enumerated into six units of analysis, rated on five-point scale, and were discussed on the basis of their relatively intensity. Leading Pakistan is a stressful experience. Musharraf optimistically portrays his followers as peace loving. The leader's life experiences and leadership practices are more based on determinism rather than freewill. Musharraf appears to be narcissistic. The leader possesses liberal ideology which stems from his parents' liberal values and his entire education from either secular institutions or missionary schools. The book reveals multiple states of conflicts most of which are dysfunctional in nature and in part a dominant reason of military intervention into state affairs. Musharraf handled the conflict with a dominating style. Musharraf used referent power during military takeover and coercive power to lead the country. Musharraf appears as an autocratic and pseudo-consultative decision maker. Outcomes proved that his decision to join US in the war against terrorism was wrong. Musharraf was extrinsically motivated to lead the army and the nation. Early childhood experiences, training and education played a vital role in the leadership development of Musharraf. Musharraf proposed the vision 'enlightened moderation' to cut short the distances between the west and the Islamic world. Due to the controversial position of the author in Pakistan and the world, the memoir cannot be completely relied but still it is informative in understanding the leadership practices of a military leader in the context of $9 / 11$.

\section{References}

Akhtar, T. (1991). Assessment of leadership potential in armed forces. Unpublished M. Phil dissertation, National Institute of Psychology, Quaid-i-Aam University Islamabad, Pakistan.

Ali, A. (1989). Decision styles and work satisfaction of Arab executives: a cross- national study. International Studies of Management and Organization, 19(2), 22-37.

Almas, S. (2007). Leadership styles as predictors of conflict management styles. Unpublished M. Phil dissertation, National Institute of Psychology, Quaid-i-Azam University Islamabad, Pakistan. 
Avoilo, B. J., \& Bass, B. M. (2002). Developing potential across a full range of leadership: Cases on transactional and transformational leadership. Mahwah, NJ: Lawrence Erlbaum.

Bass, B. M., \& Riggio, R. E. (2006). Transformational leadership. (2nd ed.). Mahwah, NJ: Lawrence Erlbaum.

Baumeister, Roy F., E. J. Masicampo, \& C. Nathan DeWall (2009). Pro-social Benefits of Feeling Free: Disbelief in Free Will Increases Aggression and Reduces Helpfulness. Personality and Social Psychology Bulletin, 35(2), 260-268.

Bedeian, A. G., \& Hunt, J. G. (2005). Academic amnesia and vestigial assumptions of our forefathers. Unpublished Manuscript, Area of Management. The Texas University Press.

Campbell, K. W., \& Foster, J. D. (2007). The Narcissistic Self: Background, an Extended Agency Model, and Ongoing Controversies. In C. Sedikides \& S. Spencer (Eds.), Frontiers in social psychology: The self. Philadelphia, PA: Psychology Press.

Ciulla, J. B. (2003). The ethics of leadership. Belmont, CA: Wadsworth Thomson Learning.

Dixon, F. N. (1976). On the psychology of military incompetence. (1st ed.). New York: Jonathan Cape Inc.

French, J., \& Raven, B. H. (1959). The bases of social power. In D. Cartwright (Ed.) Studies of social power. Ann Arbor, MI: Institute of Social Research.

Goleman, D. (2000). Leadership that gets results. Harvard Business Review, 78(2), 18-79.

Greenberg, J., \& Baron, R. A. (2000). Behavior in organizations. (5th ed.). New Delhi: Prentice Hall.

Johnson, C. R. (2005). Meeting the ethical challenges of leadership (2nd ed.). Thousand Oaks, CA: Sage Publications.

Kinicki, A., \& Kreitner, R. (2006). Organizational behavior: Concepts, skills and practices (2nd ed.). New Delhi: McGraw-Hill.

Kirkpatrick, S. A., \& Locke, E. A. (1991). Leadership: Do this matter? The Executive, 5, 48-60.

Lord, R. G., DeVader, C. L., \& Alliger, G. M. (1986). A meta-analysis of the relation between personality traits and leadership perceptions: An application of validity generalization procedures. Journal of Applied Psychology, 71, 402-410.

Manning, G. \& Curtis, K. (2003). The art of leadership (1st ed.). New York: McGraw-Hill Companies, Inc.

Mcshane, S., \& Travaglione, T. (2004). Organizational behavior of the Pacific Rim. Australia: McGraw Hill.

Muchinsky, P. M. (2007). Psychology applied to work: An introduction to industrial and organizational psychology. (8th ed.). New Delhi: Thomson Wadsworth.

Musharraf, P. (2006). In the Line of Fire. New York: Simon and Schuster.

Myers. D. G. (2008). Psychology (6th ed.). McGraw Hills: New York.

Northouse, P. (2007). Leadership: Theory and practice. Thousand Oaks, CA. Sage.

Quinn, R. (1988). Beyond rational management: Mastering the paradoxes and competing leadership demands of high performance. San-Francisco: Jossey-Bass.

Rahim, M. A. (2001). Managing conflict in organizations (3rd ed.). Wesport, CT: Quorum Books.

Riaz, M. N. (2006). Content analysis of In the Line of Fire: Military leadership in practice. Unpublished M.Sc research report, National Institute of Psychology, Quaid-i-Azam University Islamabad, Pakistan.

Riaz, M. N. (2009). Leadership styles as predictors of decision-making styles. Unpublished M. Phil dissertation, National Institute of Psychology, Quaid-i-Azam University Islamabad, Pakistan.

Riaz, M. N., Anis-ul-Haque, M., \& Hassan, B, (2009). Role of individual and organizational factors in leadership. Pakistan Journal of Psychology, 12(2), 12-15.

Satterfield, J. M., \& Seligman, M. E. P. (1994). Military aggression and risk predicted by explanatory style. Psychological Science, 5, 77-82.

Schultz, D. P., \& Schultz, S. E. (2009). Theories of Personality (9th ed.). Belmont, CA: Cengage Learning/Wadsworth.

Sekaran, U. (2008). Organizational behavior: Text and cases (9th ed.). New Delhi: McGraw-Hill.

Shahab, Q. (2005). Shahab Nama (19th ed.). Lahore: Sang-e-Meel Publications.

Suedfield, P., \& Rank, A. (1976). Revolutionary leaders: Long term success as a function of changes in conceptual complexity. Journal of Personality and Social Psychology, 34, 169-178. 
Vohs, Kathleen D., Jonathan W., \& Schooler (2008). The value of believing in free will. Psychological Science, 19(1), 49-54.

White, R. K. (1949). Hitler, Roosevelt, and the nature of war propaganda. Journal of Abnormal and Social Psychology, 44, 157-174.

Yukl, G., \& Taber, T. (2002). A hierarchical taxonomy of leadership behavior: Integrating a half century of behavior research. Journal of Leadership and Organizational Studies, 9(1), 15-32.
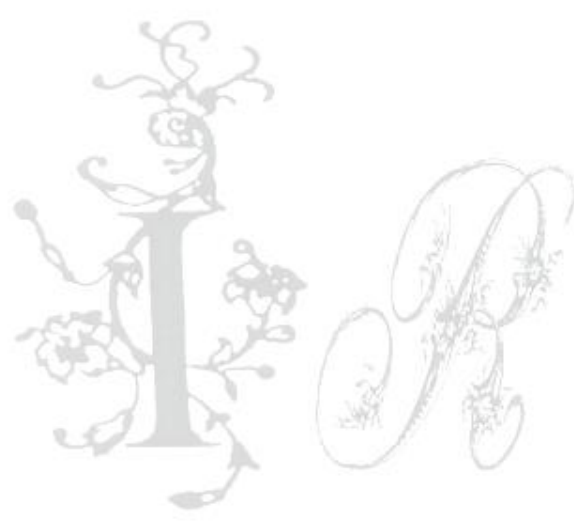